\title{
ARCHAEOLOGIA:
}

OR,

\section{ISCELLANEOUS TRACTS}

RELATING TO

\section{A N T I Q U I T Y}

VOLUME II. 


\section{ARCHAEOLOGIA: O R,}

\section{ISCELLANEOUS TRACTS}

RELATING TO

\section{A N T I Q U ITY.}

PUBLISHED BY

THE SOCIETY OF ANTIQUARIES OF LONDON.

V O L U M E II.

SE C O N $\overline{\overline{D E D}}$ I T I O N.

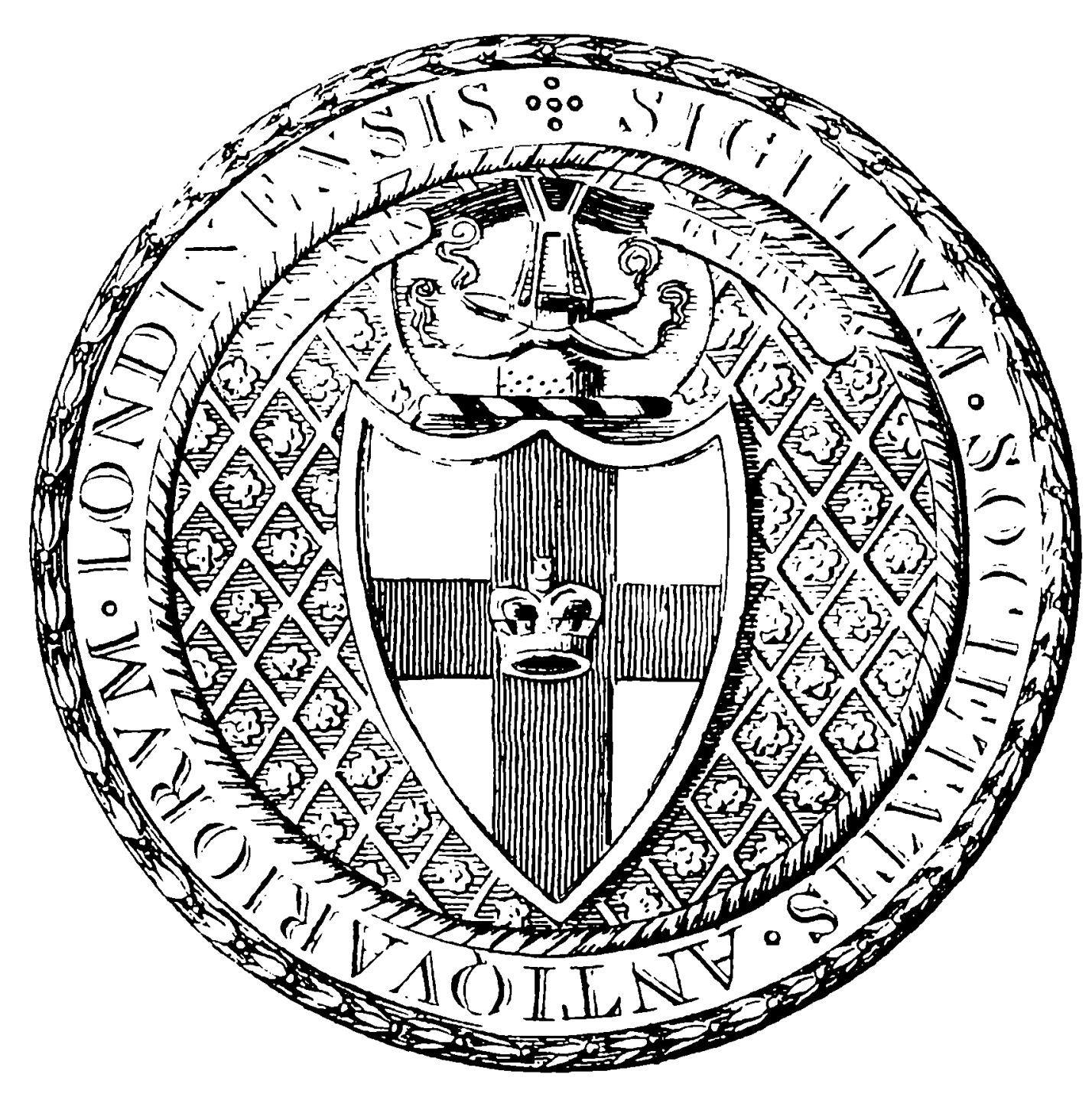

L O N D O N:

Printed by T. Benslex, Bolt Court, Fleet Street.

Sold at the Societr's Apartments in Somerset Place; and by Meffeur; White, Nornanville and Feli, Nicor, Leigh and Sothebr, Bickerstafa, Cadell and Davies,

Egerton and TAYLOR.

M DCCC IX. 


\section{$\left[\begin{array}{ll}\mathrm{v} & ]\end{array}\right.$}

\section{T A $\quad$ B $\quad$ L $\quad$ E \\ OF}

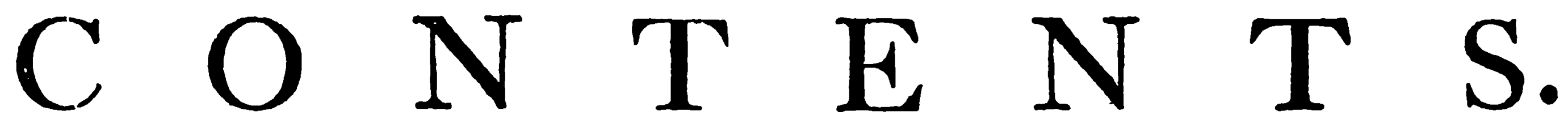

I. Obfervations on the Julia Strata, and on the Roman Stations, Forts, and Camps, in the Counties of Monmouth, Brecknock, Caermarthen, and Glamorgan. By the Reverend William Harris, Prebendary of Landaff, and Curate of Caireu. p. I II. Obfervations on an Infcription at Spello. By F. Paffarini, and Roger Gale, Efquire.

p. 25 .

III. An Account of fome Antiquities, found in Ireland; communicated by the Right Rev. Richard Pococke, late Lord Bihhop of Meath.

IV. Differtation on an ancient Cornelian. By the Reverend Mr. Hodgfon.

V. An Account of an ancient Monument in Penrith Cburcb-yard, Cumberland. By Dr. Lyttelton, then Dean of Exeter. p. 48 VI. An Account of fome Antiquities difcovered on digging into a large Roman Barrow at Elenborough, in Cumberland, 1763 . By the Rev. Mr. Head, Prebendary of Carlifle

VII. Account of fome Roman Monuments found in Cumberland, I766.

p. $5^{8}$

VIII. $A$ Differtation on the Gule of Auguft, as mentioned in our Statute Laws. By John Pettingal, D. D. p. 6o IX. Obfervations on the Miftakes of Mr. Lifle and Mr. Hearne, in refpect of King Alfred's Prefent to the Catbedrals. The late 
Uje of the Stylus, or Metalline Pen. Mr. Wife's Conjecture concerning the famous Jewel of King Alfred further purfued; Sewing it might pofibly be part of the Stylus fent by that King with Gregory's Paftoral, to the Monaftery at Athelney, By $M r$. Pegge.

X. Obfervations on the Aeftel. By the Rev. Dr. Milles, in a Lettor to the Right Rev. the Lord Bifhop of Carline, Prefident. p. 75 XI. Obfervations on Mr. Peter Collinfon's Paper on the Round. Towers in Ireland, printed Vol. I. p. 305. By Owen Salurbury Brereton, $E / q ; F . R$. S. and $A$. S.

p. 80

XII. Obfervations on the Round Tower at Brechin in Scotland. By Richard Gough, $E$ fq.

p. 83

XIII. The Bull-running, at Tutbury, in Staffordnire, confidered. By the Reverend Mr. Pegge. p. 86 XIV. Obfervations on a Altar, with a Greek Infcription, at Corbridge, in Northumberland. By the Rev. Dr. Pettingal. p. 92 $\mathrm{XV}$. Obfervations on the fame Infcription. By Dr. Adee, in a Letter to the Reverend Dr. Milles.

p. 98

XVI. Objervations on Dr. Percy's Account of Minftrels among the Saxons. By Mr. Pegge.

p. 100

XVII. An Account of the Monument commonly afcribed to Catigern. By Mr. Colebrooke.

p. 107

XVIII. Obfervations on Stone Hatchets. By Bißop Lyttelton. p. I I 8 XIX. Obfervations on Stone Hammers. By Mr. Pegge. p. I 24 $\mathrm{XX}$. Objervations on an Infcription in the Cburch at Sunning-hill, Berks. By Dr. Milles, Dean of Exeter, and Prefident of the Society.

p. 129

XXI. Defcription of an ancient Font at Bridekirk, in Cumberland. By Bifhop Lyttelton.

p. I 3 I

XXI:. Obfervations on Cæfar's Invafion of Britain; and more particularly bis Pafage acros the Thames. By the Hon. Daines Barrington. 
Barrington. In two Letters, addrefJed to the late Bifhop of Carlinle.

p. 134

XXIII. Remarks on the Time employed in Caefar's two Expeditions into Britain. By the Reverend Dr. Owen, of St. Olave's, HartAtreet; communicated by the Honourable Daines Barrington. p. 159 XXIV. Copy of a Draught of a Proclamation in the Year ${ }_{15} 6_{3}$, relating to Perfons making Portraits of Queen Elizabeth. From the Original Draught in the Paper-office in the Hand-writing of Secretary Cecil, with his corrections, and among his papers; communicated by Sir Jofeph Ayloffe, Bart.

p. 169

XXV. A Difertation on the Crane, as a Difh ferved up at great Tables in England. By the Reverend Mr. Pegge.

p. I $7 \mathbf{I}$ XXVI. An Account of a Roman Sepulcbre found near York, in I 768. By John Burton, M. D.

p. 177 XXVII. Extract of two Letters from Dr. John Burton, of York, to Dr. Ducarel, concerning Roman Antiquities difcovered in York hire, 1770.

p. I 8 I XXVIII. The Conftruction of the old Wall at Verolam. The Roman Bricks compared with the modern, \&c. In a Letter to Bifhop Lyttelton. By Mr. Webfter.

XXIX. Conjectures on an ancient Tomb in Salifbury Catbedral. By Mr. Gough.

p. 188

XXX. An Account of an illuminated MS. in the Library of C. C. C. Cambridge. By the Reverend Mr. Tyfon, Fellow of the faid College.

p. 194

XXXI. Some Remarks on Mr. Walpole's Hiftoric Doubts on the Life and Reign of King Richard the Tbird. By Robert Malters, B. D. and Rector of Landbeach, in Cambridgefhire. p. 198 XXXII. Obfervations on a Greek Infcription brougbt from Athens. By Daniel Wray, E/quire. 
viil

XXXIII. Some Account of certain Tartarian Antiquities. In a Letter from Faul Demidoff, E/quire, at Peternburgh, to $\mathbf{M r}$. Peter Collinfon, dated September i6, i 764 .

p. 222

XXXIV. Obfervations on fome Tartarian Antiquities, defcribed in the preceding Article. By John Reinhold Forfter, F. A. S. p. 227 XXXV. A Defiption of the Sepulcbral Monument at New Grange, near Drogheda, in the County of Meath, in. Ireland. By Thomas Pownall, Efquire. In a Letter to the Reverend Gregory Sharpe, D. D. Mafter of The Temple.

p. 236

XXXVI. $A$ fuccind and autbentic Narrative of the Battle of Cherterfield, A. D. I 266, in the Reign of King Henry III. By Mr. Pegge.

p. 2,76

XXXVII. Account of a Roman Pavement, with Wheat underneath it, found at Colchefter. By the Reverend Dr. Griffith; communicated by Edw. King, E/q. in a Letter to the Secretary. p. 286 XXXVIII. Mr. Lethieullier's Obfervations on Sepulcbral Monuments. In a Letter to James Weft, ESquire.

p. $29 \mathrm{I}$

XXXIX. $A$ View of the ancient Confitution of the Englifh Parliament. By Francis Maferes, Efq. of the Inner Temple. p. $30 \mathrm{I}$ $\mathrm{XL}$. Obfervations on Mr. Maferes's Viewe of the ancient Conftitution of the Englifh Parliament. By Charles Mellifh, Efquire. In a Letter to the Rev. Mr. Norris, Secretary to the Society of Antiquaries.

p. $34 \mathrm{I}$

XLI. Druidical Remains in or near the Parifh of Halifax in Yorkthire, difiovered and explained, by the Rev. John Watfon, $M . A$. F. S. A. and Rector of Stockport, in Chenhire.

XLII. Extract of a Letter from the Rev. Mr. Bentham of Ely to the Dean of Exeter, concerning certain Difcoveries in Ely Minfter.

p. $3^{64}$ 